\title{
Determination Safe Duration of Exposure to Benzene in Workers of Petrolium Processing Industrial Laboratory in Indonesia by Using Noael of White Mice (Rattus norvegicus)
}

\author{
Ermita Isnaeni Putri Susyanti ${ }^{1}$, Abdul Rohim Tualeka ${ }^{1}$, Pudji Rahmawati ${ }^{2}$, Syamsiar S Russeng ${ }^{3}$, Atjo \\ Wahyu $^{3}$, Ahsan $^{4}$, Dewi Kartikasari ${ }^{5}$ \\ ${ }^{1}$ Department of Occupational Health and Safety, Public Health Faculty, Airlangga University, 60115, \\ Surabaya, East Java, Indonesia; ${ }^{2}$ Department of Development of Islamic Society, State Islamic University \\ Sunan Ampel, Surabaya, Indonesia; ${ }^{3}$ Department of Occupational Health and Safety, Public Health \\ Faculty, Hassanudin University, Makassar, Indonesia; ${ }^{4}$ Faculty of Nurse, University of Brawijaya, \\ Malang, Indonesia; ${ }^{5}$ Department of Environtmental Health, Faculty of Public Health, Diponegoro \\ University, Semarang, Indonesia
}

\begin{abstract}
Benzene is a volatile liquid aromatic hydrocarbon. Benzene is also used in industries related to oil processing, one of which is fuel. According to the Agency for Toxic Substances and Disease Register (ATSDR), toxic chemicals contained in oil includes Policyclic Aromatic Hydrocarbons (PAHs), Total Petroleum Hydrocarbon (TPH), benzene, ethylene and toluene. Of all these toxin substances, benzene is the most dangerous chemical and exposure to benzene has a serious impact on human health. As a form of control effort, determining the safe duration of exposure (Dt) for benzene exposure based on the value of RfC (Reference of Concentration) using NOAEL (No Observed Adverse Effect Level) of white mice (Rattus norvegicus) is needed. This study aimed to determine the value of No Observed Adverse Effect Level (NOAEL) of white mice (Rattus norvegicus), safe limits of toxin dosage for the community or Reference of Concentration (RfC), Risk Quontient (RQ) and safe duration of exposure (Dt) in laboratory workers. This was a cross sectional, observational, and descriptive study with 51 samples of PT Pertamina RU IV Cilacap laboratory workers. The object sample used in this study was the air in the work area of the main laboratory section and the petrochemical and gas laboratory of PT Pertamina RU IV Cilacap. The results of this study indicated that safe duration of exposure (Dt) was 19 years; under normal safe duration of exposure for workers. The safe duration of exposure (Dt) can be a reference for the relevant company to consider the workers' working period and reduce the exposure duration with benzene to prevent significant health impact on workers.
\end{abstract}

Keywords: Benzene, safe duration, laboratory workers, petroleum processing industry

\section{Introduction}

\section{Corresponding Author:}

Abdul Rohim Tualeka

Department of Occupational Health and Safety, Public Health Faculty, Airlangga University, 60115

Surabaya, East Java, Indonesia

Phone: +62-31-5920948

Email: abdul-r-t@fkm.unair.ac.id
Benzene, C6H6, is a volatile liquid aromatic hydrocarbon. Benzene's properties are colorless, volatile, flammable, and distinctive odors ${ }^{1}$. PT Pertamina is an industry in Indonesia that provides fuel to meet the consumption of the Indonesian people. The products include pertamax plus, pertamax, pertalite, and premium which have benzene levels of around $1 \%-5 \%{ }^{3}$. Toxic chemicals contained in oil content include Policyclic Aromatic Hydrocarbons (PAHs), Total Petroleum Hydrocarbon (TPH), benzene, ethylene and toluene. ${ }^{4}$ Of these toxins, benzene is the most dangerous chemical and exposure to benzene has a serious impact on human health. 
A previous research by Dewi Kartikasari, Nurjazuli, Mursid Rahardjo (2016) determined the value of RfC (Reference of Concentration) based on established by IRIS (Integrated Risk Information System) of USEPA by $0.03 \mathrm{mg} / \mathrm{m}^{3}$ or equivalent to $0.0085 \mathrm{mg} / \mathrm{kg} /$ day. The previous study still using references from research in America or Europe so that they cannot be used as a reference in determining risk in Indonesia so that previous study did not obtain RfC value using NOAEL (No Observed Adverse Effect Level) of white mice (Rattus norvegicus). Saridewi and Tualeka (2012) determined the value of RfC by using the formula for calculating RfC with NOAEL of white mice (Rattus norvegicus) and $\mathrm{RfC}$ value of $0.004 \mathrm{mg} / \mathrm{kg}$ was obtained.

Based on previous studies, it is obvious the safe duration of toxin exposure in an industry cannot be taken based on the results of research elsewhere. Therefore, in this study, the determination of safe duration of benzene exposure based on RfC by using NOAEL of white mice (Rattus norvegicus) is explained. The aims of this reserarch is to determine NOAEL benzene using of white mice (Rattus norvegicus), average height and weight of workers in Indonesia, Reference Concentration (RfC) and safe duration of exposure (Dt).

\section{Material and Method}

This is an observational, cross sectional and descriptive study. The subjects in this study were all 85 workers in the Laboratory section who worked in the Main Laboratory of PT Pertamina RU IV Cilacap. The object used in this study was ambient air working area Laboratory PT Pertamina RU IV Cilacap. The sample size was 51 workers, while the object sample used in this study was air in the work area of the Main Laboratory and Petrochemical and Gas Laboratory of PT Pertamina RU IV Cilacap.

The variables of this study were the concentration of benzene in the work area in the laboratory, body weight of workers, height of workers, respiratory rate of workers, duration of exposure in a day, body surface area of workers, weight of white mice (Rattus norvegicus), body surface of white mice (Rattus norvegicus), highest dose of toxin without effect on experimental animals (NOAEL), Km factor in animals (Animal $\mathrm{Km}$ ), $\mathrm{Km}$ factor in human in (Human Km), safe limit of dose of toxin for the community or Reference of Concentration (RfC), Risk Quontient (RQ) and safe duration of exposure (Dt) in laboratory workers.
The RfC formula used in this study is ${ }^{5}$ :

$$
\mathrm{RfC}=\text { NOAEL } \frac{\text { Animal Km }}{\text { Human Km }}
$$

\section{Explanation:}

RfC: Reference Concentration ( $\mathrm{mg} / \mathrm{kg}$ )

NOAEL: No Observed Adverse Effect Level (mg/kg)

Animal Km: Km factor on animal

Human Km: Km factor on human

Data analysis was carried out quantitatively to determine the safe duration of benzene exposure in laboratory workers.

\section{Findings}

A. Characteristics of Experimental Animal and Surface Area of the Experimental Animal (Rattus norvegicus): The general toxicity of a compound can be interpreted as a potential chemical that causes damage when entering the human body ${ }^{6}$. Toxicity test was carried out using white mice (Rattus norvegicus) as the research objects or experimental animal. Based on the weight of white mice (Rattus norvegicus), the body surface area of the animal can be calculated using the following formula:

Animal BSA $=0.09 \times \mathrm{W}^{0.67}$

\section{Explanation:}

BSA: Body Surface Area (m2)

W: Weight $(\mathrm{kg})$

Table 1: Characteristic Distribution of Experimental Animal (Rattus norvegicus)

\begin{tabular}{|c|c|c|}
\hline $\begin{array}{c}\text { Experimental animal } \\
\text { (Rattus norvegicus) }\end{array}$ & W (kg) & BSA ( $\left.\mathbf{m}^{2}\right)$ \\
\hline 1 & 0.1405 & 0.0241 \\
\hline 2 & 0.1405 & 0.0241 \\
\hline 3 & 0.1410 & 0.0242 \\
\hline 4 & 0.1410 & 0.0242 \\
\hline 5 & 0.1395 & 0.024 \\
\hline 6 & 0.1415 & 0.0242 \\
\hline Total & 0.844 & 0.1448 \\
\hline Average & 0.1407 & 0.0241 \\
\hline
\end{tabular}


B. Characteristics, Body Surface Area and Worker's Respiratory Rate: The characteristics of workers included in this study were body weight, height, working period and worker breathing rate in 51 workers of PT Pertamina RU IV Cilacap laboratory. Based on Table 2, the average body weight is $67 \mathrm{~kg}$. The average height of workers is $159 \mathrm{~cm}$. The surface area of the body and the respiration rate of the workers were $1.72 \mathrm{~m} 2$ and the average breathing rate was $0.596 \mathrm{~m}^{3} /$ hour.

Based on data on workers' weight and height, the body surface area and worker breathing rate can be calculated using the following formula:

A. The average body surface rate of the worker

$$
\mathrm{BSA}=\sqrt{\frac{\mathrm{W} \times h}{3600}}=\sqrt{\frac{67 \times 159}{3600}}=1.72 \mathrm{~m}^{2}
$$

\section{Explanation:}

BSA: Body Surface Area $\left(\mathrm{m}^{2}\right)$

W: Weight (kg)

$h$ : Height $(\mathrm{cm})$

B. Respiratory rate

$\mathrm{BR}=\frac{5.3 \times \ln \mathrm{W}-6.9}{24}=\frac{5.3 \times \ln 67-6.9}{24}=0.596$ Explanation:

BR: Breathing Rate $\left(\mathrm{m}^{3} / \mathrm{jam}\right)$

W: Weight (kg)

Table 2: Distribution of Worker Characteristics, Worker's Body Surface Area, Employee Respiratory Rate and Average Duration of Workers in the Petroleum Processing Industry Laboratory Section

\begin{tabular}{|c|c|c|c|c|c|}
\hline 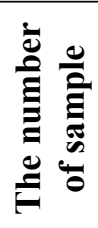 & 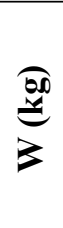 & $\underbrace{\overparen{E}}_{=}$ & 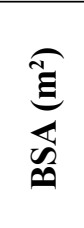 & 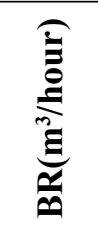 & \\
\hline 51 & 67 & 159 & 1.72 & 0.596 & 8 \\
\hline
\end{tabular}

C. Benzene Concentration: The risk level for minimum risk level (MRL) is acute exposure $(\leq 14$ days $)=0.009(0.028 \mathrm{mg} / \mathrm{m} 3)$, moderate exposure $(15-365$ days $))=0.006 \mathrm{ppm}(0.019 \mathrm{mg} /$ $\mathrm{m} 3)$, and chronic exposure $(>365$ days $)=0.003$ ppm $(0.009 \mathrm{mg} / \mathrm{m} 3)^{2}$ determination of quantitative trait loci, and phylogenetic comparison. Genome sequencing analysis of inbred mouse strains has identified high-density single nucleotide polymorphisms (SNPs. This indicates that the concentration of benzene in the laboratory work area of PT Pertamina RU IV Cilacap is above the minimum risk level (MRL) ${ }^{2}$.

Table 3: Benzene concentration in PT Pertamina RU IV Cilacap Laboratory Section

\begin{tabular}{|c|c|}
\hline Location & $\begin{array}{c}\text { Concentration } \\
\text { (ppm) }\end{array}$ \\
\hline Observation table 1 & 0.011 \\
\hline Observation table 2 & 0.006 \\
\hline Shelter D & 0.169 \\
\hline KR Room & 0.059 \\
\hline Observation table 3 & 0.139 \\
\hline Observation table 4 & 0.187 \\
\hline R \& D analysis table & 0.073 \\
\hline Administration room & 0.069 \\
\hline Average & 0.09 \\
\hline
\end{tabular}

D. Animal Km and Human Km

1. Animal Km: Determination of safe dosage of toxin for workers begins with the calculation of Animal $\mathrm{Km}$. Animal $\mathrm{Km}$ is obtained by using the following formula:

Animal $\mathrm{Km}=\frac{\mathrm{W} \text { animal }}{\mathrm{BSA} \text { animal }}$
Explanation:

Animal Km: Km factor on animal

W: Experimental animal body weight (white mice or Rattus norvegicus) (kg)

BSA: Surface area of experimental animals $\left(\mathrm{m}^{2}\right)$

Table 4: Calculation of Animal Km in Experimental Animal of White Mice (Rattus norvegicus)

\begin{tabular}{|c|c|c|c|}
\hline 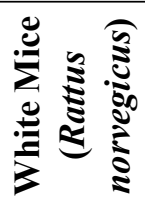 & 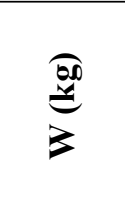 & 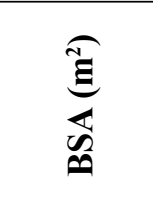 & 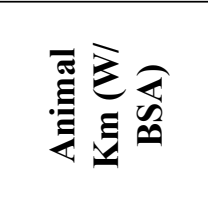 \\
\hline 1 & 0.1405 & 0.024165 & 5.814194082 \\
\hline 2 & 0.1405 & 0.024165 & 5.814194082 \\
\hline 3 & 0.1410 & 0.024223 & 5.820914007 \\
\hline 4 & 0.1410 & 0.024223 & 5.820914007 \\
\hline 5 & 0.1395 & 0.024050 & 5.8004158 \\
\hline 6 & 0.1415 & 0.024165 & 5.855576247 \\
\hline Average & 0.1407 & 0.024165 & 5.82 \\
\hline
\end{tabular}


2. Human Km: The Human $\mathrm{Km}$ calculation is performed by using the following formula:

Human $\mathrm{Km}=\frac{\mathrm{W} \text { human }}{\text { BSA human }}$

Explanation :

Human Km: Km factor in humans

W: Human Weight $(\mathrm{kg})$

BSA: Body Surface $\left(\mathrm{m}^{2}\right)$

Tabel 5: The Average of Human Km

\begin{tabular}{|c|c|c|c|}
\hline $\begin{array}{c}\text { The number } \\
\text { of sample }\end{array}$ & W (kg) & BSA $\left(\mathbf{m}^{2}\right)$ & $\begin{array}{c}\text { Human Km } \\
\text { (W/BSA) }\end{array}$ \\
\hline 15 & 67 & 1.72 & 38.95 \\
\hline
\end{tabular}

E. NOAEL (No Observed Adverse Effect Level): No Observed Adverse Effect Level (NOAEL). NOAEL benzene is $0.022 \mathrm{mg} / \mathrm{kg}^{7}$, obtained from the calculation of the following formula:

NOAEL Benzene $=3 \mathrm{mg} / \mathrm{m}^{3}$

$$
\mathrm{NOAEL}=\frac{3 \times 0.00013 \times 8}{0,1405}=0.022 \mathrm{mg} / \mathrm{kg}
$$

F. Reference Concentration (RfC): Reference concentration according to Shaw et al (2007) in Saridewi and Tualeka (2017) uses the following formula:

$$
\begin{aligned}
& \mathrm{RfC}=\text { NOAEL } \frac{\text { Animal Km }}{\text { Human Km }} \\
& \text { Explanation: }
\end{aligned}
$$

\section{RfC: Reference Concentration $(\mathrm{mg} / \mathrm{kg})$}

Animal Km: Km factor in white mice (Rattus norvegicus)

Human Km: Km factor on workers

Based on the formula above, the RfC calculation results obtained from NOAEL, Animal $\mathrm{Km}$ averages, and the Human Km averages are:

$$
\mathrm{RfC}=0.022 \frac{5.82}{38.9}=0.003 \mathrm{mg} / \mathrm{kg}
$$

G. Risk Quotient (RQ): Health risk characteristics are expressed as risk levels or risk quotient (RQ) for carcinogenic effects $489{ }^{10}$. RQ calculations) are obtained by the following formula ${ }^{11}$ :

$$
\mathrm{RQ}=\frac{\mathrm{Ink}}{\mathrm{RFc}}
$$

Explanation:

Ink: Intake the amount of risk agent that an individual receives $(\mathrm{mg} / \mathrm{kg} /$ day)

RfC: Reference Concentration (mg/kg)

For the characteristics of non-carcinogenic risks, the risk agent intake received by individuals is determined by the following formula:

$\frac{\mathrm{C} \times \mathrm{Br} \times t \mathrm{E} \times f \mathrm{E} \times \mathrm{D} t}{\mathrm{~W} b \times t \text { Avg (non carcinogen })}$

$=\frac{0,09 \times 0,596 \times 8 \times 265 \times 12,55}{67 \times 30 \times 365}$

$=0,019 \mathrm{mg} / \mathrm{kg} /$ day

Explanation:

$\mathrm{C}$ :The concentration of toxins in the air that is safe for workers $\left(\mathrm{mg} / \mathrm{m}^{3}\right)$

Br: Breathing rate $\left(\mathrm{m}^{3} /\right.$ hour $)$

tE: Daily exposure time (hours/day)

fE: Frequency of annual exposure (day/year)

Dt: Exposure duration (years)

$\mathrm{Wb}$ : Worker's weight $(\mathrm{kg})$

Tavg: Average time period (days/years)

Then the RQ calculation is as follows:

$\mathrm{RQ}=$ Intake $/ \mathrm{RfC}=0,019 / 0,003=6,34(\mathrm{RQ}>1)$

H. Safe Duration Of Exposure To Benzene: The safe duration can be determined using the following formula:

$\mathrm{D} t(\mathrm{safe})=\frac{\mathrm{R} f \mathrm{C} \times \mathrm{W} b \times t \text { avg }}{\mathrm{C} \times \mathrm{B} r \times t \mathrm{E} \times f \mathrm{E}}$

Explanation:

$\mathrm{D} t$ (safe): Safe duration of exposure for workers (years)

RfC: Reference Concentration ( $\mathrm{mg} / \mathrm{kg}$ )

T avg: Average time (days)

$\mathrm{C}$ : Concentration in air $(\mathrm{mg} / \mathrm{m} 3)$

BR: Breathing rate/working breathing rate $\left(\mathrm{m}^{3} /\right.$ hour)

$t \mathrm{E}$ : Length of exposure time (hours/day)

$f \mathrm{E}$ : Frequency of exposure (day/year) 
Then Dt (safe) calculation is as follows:

$$
\mathrm{D} t(\mathrm{safe})=\frac{0,003 \times 67 \times(30 \times 365)}{0,09 \times 0,596 \times 8 \times 265}=19 \text { years }
$$

The results of this calculation can be used as a reference for the relevant companies to control benzene exposure so that it does not have a health impact on their workers.

\section{Discussion}

Based on research conducted by Swan et al (2010) states that NOAEL benzene is $3.0 \mathrm{mg} / \mathrm{m}^{3}$ or its value is equivalent to $0.022 \mathrm{mg} / \mathrm{kg}$. Based on the results of this study, the calculation of NOAEL benzene value in white mice (Rattus norvegicus) is $0.022 \mathrm{~m} / \mathrm{kg}$. Thus, the results of this study are safe for human.

The present study used inhalation route that the response dose for the non-carcinogenic effect used was the Reference Concentration (RfC) value. Benzene RfC value in this study was carried out by using NOAEL of white mice (Rattus norvegicus). The research conducted by Tualeka AR, Wibrata DA, Ahsan A, et al (2019) indicated that NOAEL could experimentally determine doses where there was no statistically significant indications of toxic effects or biological problems. The study conducted by Saridewi and Tualeka (2012) obtained a benzene RfC value using NOAEL of white mice (Rattus norvegicus) is $0.004 \mathrm{mg} / \mathrm{kg}$. Based on the results of this study, the calculation of benzene $\mathrm{RfC}$ values in white mice (Rattus norvegicus) is $0.003 \mathrm{mg} /$ $\mathrm{kg}$. The value of Benzene obtained in the present study was smaller than those of Rendy's (2012) obtained a benzene $\mathrm{RfC}$ value is $0.01 \mathrm{mg} / \mathrm{kg}$. It is also smaller than the results of a study conducted by Dewi Kartikasari, Nurjazuli, Mursid Rahardjo (2016) obtained a benzene $\mathrm{RfC}$ value is $0.0086 \mathrm{mg} / \mathrm{kg}$. Thus results of this study are safer for humans by using NOAEL of white mice (Rattus norvegicus) as a calculation of $\mathrm{RfC}$.

Toxins with potential to produce non-cancerous or non-carcinogenic effects, the health assessment ratio is stated by Risk Quotient (RQ) where RQ $>1$ is categorized as unsafe or risky ${ }^{4}{ }^{10}$. In the calculation, RQ less than 1 $(\mathrm{RQ}<1)$ does not affect the body, but RQ value of more than $1(\mathrm{RQ}>1)$ is dangerous ${ }^{11}$. Therefore, it is necessary to control the effect by determining the safe duration of exposure (Dt) value. Based on the results of this study, the value safe duration of benzene exposure in PT Pertamina RU IV Cilacap laboratory work environment was 19 years.

\section{Conclusion}

a. Benzene concentration in the laboratory work area at PT Pertamina RU IV Cilacap was $0.09 \mathrm{ppm}$. This is below the threshold value that allowed in Indonesia according to Permenakertrans No.5/ MEN/X/2018 on Threshold Value of Physical Factors and Chemical Factors in the Workplace of $0.5 \mathrm{ppm}$.

b. NOAEL Benzene in the laboratory work area of PT Pertamina RU IV Cilacap was $0.022 \mathrm{mg} / \mathrm{kg}$.

c. Reference Concentration (RfC) in the laboratory work area at PT Pertamina RU IV Cilacap was $0.003 \mathrm{mg} / \mathrm{kg}$.

d. The level of risk was unsafe with RQ value $>1$

e. The safe duration of exposure to benzene in the laboratory work area of PT Pertamina RU IV Cilacap was 19 years.

\section{Recommendation}

The safe duration of exposure to benzene for noncarcinogenic laboratories at PT Pertamina RU IV Cilacap was 19 years. This figure was smaller than the normal workers safe duration of exposure of 30 years. To normalize safe duration of exposure, the concentration of toxin must be minimized to adjust the safe limit of toxin concentration for workers and daily exposure duration was also smaller than 8 hours/day.

Conflict of Interest: All author have no conflicts of interest to declare

Source of Funding: This is an articel about "Determination Safe Duration Of Exposure To Benzene In Workers Of Petrolium Processing Industrial Laboratory In Indonesia By Using NOAEL Of White Mice (Rattus Norvegicus)" of Occupational Health and Safety Departmen that was supported by Faculty of Public Health, Airlangga University.

Ethical Clearence: The study was approved by the institutional Ethical Board of the Public Health, Diponegoro University. 


\section{REFERENCES}

1. Pillay V. Modern Medical Toxicology. fourth. New Delhi, India: Jaypee Brothers Medical Publishers; 2013. p.378

2. Agency for Toxic Substances and Disease Registry. Toxicological Profile for Benzene. Atlanta: Agency for Toxic Substance and Disease Registry; 2007.

3. Jakab Z. WHO Regional Office for Europe. WHO Europe; 2013

4. ATSDR. Public Health Assessment Guidance Manual. U.S. Department of Health and Human Services Public Health Service Agency for Toxic Substances and Disease Registry Atlanta, Georgia; 2005.

5. Saridewi N, Tualeka AR. Penentuan Konsentrasi Aman Benzena di Stasiun Pengisian Bahan Bakar Umum (SPBU) di Pancoranmas Depok; 2017;

6. Tualeka AR. Toxicology Industry \& Risk Assessment. Surabaya: Graha Ilmu Mulia; 2014.

7. EPA. User's Guide Biomarkers Data Base. USA; $2004 \mathrm{p}$.

8. EPA-IRIS. Toxicological Review of Benzene (Noncancer Effect) [Internet]. Available from: http://www.epa.gov/iris/toxreviews/0276tr.pdf.

9. IPCS. International Programme on Chemical Safety of WHO. IPCS risk assessment terminology. Harmonization Project Document No. 1; 2004.

10. Louvar FL and Louvar BD. Health and Environmental Risk Analysis Volume 2:
Fundamentals with Applications (Paperback). 1 edition. New Jersey: Prentice Hall; 1997. p. 704.

11. Tualeka AR. Analisis Risiko: Risk Assessment, Risk Management \& Risk Communication di Lingkungan Kerja. Surabaya: Graha Ilmu Mulia; 2015.

12. Dewi Kartikasari, Nurjazuli MR. Analisis Risiko Kesehatan Pajanan Benzene Pada Pekerja Di Bagian Laboratorium Industri Pengolahan Minyak Bumi. Jurnal Kesehatatan Masyarakat [Internet]. 2016;4:892-9. Available from: rom: http://ejournal-s1.undip.ac.id/index.php/ jkm\%0AANALISIS

13. Ramon A. Analisis paparan benzena terhadap profil darah pada pekerja industri pengolahan minyak bumi. Univ Diponegoro. 2007;

14. Noor Salim R. Analisis Risiko Kesehatan Pajanan Benzene Pada Karyawan di SPBU X Pancoranmas Depok Tahun 2011. Universitas Indonesia; 2012.

15. Tualeka AR, Wibrata DA, Ahsan A, Rahmawati P, S Russeng S, Wahyu A, et al. Determination of Highest Dose of Ammonia without Effect at Work Environment through the Expression of Interleukin-2 Cell in Rattus Novergicus. Macedonia Journal of Medical Science. 2019; p.207.

16. Menteri Ketenagakerjaan Republik Indonesia. Peraturan Menteri Ketenagakerjaan Republik Indonesia Nomor 5 Tahun 2018; 2018. 